\title{
The Literary Instant and the Condition of Being Hostage: Levinas, Proust, and the Corporeal Meaning of Time
}

Literature is present everywhere in the philosophical work of Emmanuel Levinas, but this omnipresence does not allow itself to be circumscribed by unique narrative idioms or isolated references. One of the characteristic traits of the modernity of the twentieth century is to elicit a proximity between philosophy and literature with regard to writing and thought and, in this regard, Proust single-handedly represents what Roland Barthes in 1974 called "a complete system of reading the world. [. . . ] In our everyday life, there is not an incident, an encounter, a trait, a situation that does not have a reference in Proust" (Barthes 2002, 569). ${ }^{1}$

Emmanuel Levinas did not abandon this tradition, which, as far as France is concerned, is very old; indeed, one should immediately add that few philosophers have been as attentive to literature and poetry as he was. Furthermore, Levinas's great originality, I would even say the radicality of his gesture, is to hold the hypothesis, or at least to let it be glimpsed in his essay "Reality and Its Shadow,"2 published in Les Temps Modernes in 1948, that literature cannot be understood as "art," that the narrative word is not restricted to speaking or immersing itself in the passion of verbalism or psychological satisfaction, but that it is speech manifesting itself in the movement of telling, in the act of writing. In this sense it is already in itself an appeal to the other - that which Levinas understands as the most essential modality of "being wary of oneself," which is, as we know, characteristic of philosophy and criticism. Alongside philosophical preoccupations and priorities, in certain respects modern literature would manifest, more than or just as much as philosophy, what Levinas calls "a more and more acute awareness of this fundamental insufficiency of artistic idolatry" (Levinas 1994, 148). The development to which Levinas attests in an acutely incisive way is not that of literature but that of art, inasmuch as it is not language. Consequently, it does not attain the dignity of the question of truth and of the good, which philosophy after Plato attempts to articulate. The aesthetic

1 Barthes's comment is from an interview by Claude Jannoud, Le Figaro, 27 July 1974.

2 The text is reprinted in Levinas's Les imprévus de l'histoire (1994, 123-148).

Translation: Translated, from the French, by Ashraf Noor.

Ә Open Access. (C) 2021 Danielle Cohen-Levinas, published by De Gruyter. (c) BY This work is licensed under the Creative Commons Attribution 4.0 International License. 
temptation was condemned rigorously by Levinas already in De l'existence à l'existant (1947), begun in captivity, in the context of the immediate aftermath of the War, for the reason that it constitutes the very event of the obscuring of being and that it leads to its darkening. This is not comparable to the literary temptation expressed by Levinas in Les carnets de captivité, which, I believe, one must take very seriously and probe with great attention. A reader of Proust, certainly, but also of many other writers during this period, whom he interrogates tragically with the formulation inscribed in these notebooks, "What will history say?” (Levinas 2009, 79), Levinas detects in literature the possibility of reintroducing, into the heart of the concept's rigor, an intelligibility of the world in which the notion of "experience" takes a central role. With narrative, which has become the form of the relation to the other, Levinas broaches the status of the subject, of the subjectivity that has to face the trial of alteration, that is, of fissure and devastation. The narratives and the writers who attract his attention are undeniably all pierced by what one could call the extradition of the subject, which is the true motif of the narratives, around which a dramaturgy, what Levinas calls an intrigue, would be woven. Or rather, as he writes in the sixth Carnet de captivité: "The fear of being 'duped' - is not such a practical rule, which seems to me to be absolute, purely and simply 'literature' [?] - This sphere of literature enlarges itself infinitely. Does virtue exist?” (Levinas 2009, 161).

Levinas, then, experienced captivity, the condition of the hostage, as he himself calls it - recalling at various junctures that he has known the word "hostage" "since the persecution by the Nazis" (de Saint-Cheron 2006, 31) "[i]n the total passivity of abandonment, in detachment from all relations" (Levinas 2009, 213), and, at the same time, as a moment where "the true experiences” (Levinas 2009, 203) are revealed. Levinas's narrative has an unheard of force: "Suffering, hopelessness, mourning - certainly. Yet, above all that, a new rhythm of life. We stepped onto another planet, breathing an atmosphere of unknown composition and handling matter that no longer weighs anything" (Levinas 2009, 203).

The singular force of the word "hostage," which at once resonates with that of "captivity," is without a doubt due to the way in which Levinas displaces it in the conceptual register by revealing in it the eminence of a Saying narrating itself while being charged with an irrefutable ethical force. This is an effort striving towards what Levinas, in Autrement qu'être, calls a "thematising, thought, history and writing" (Levinas 1974, 20) that necessarily comes to be wounded not only by the trace of signifying, of "designating," and of proximity, but by lived experience and its temporalisation in the process of writing and in the exercise of thought. Levinas, then, experienced captivity. 
He was, as one says, a prisoner of war, billeted from 1942 in various Frontstalag, in Rennes, in Laval, and in Vesoul; and, from 1942 to the end of his captivity, in 1945, he was prisoner in Stalag XI B in Fallingbostel in Germany. Here, he was separated from the other French prisoners and forced to work in a special commando reserved for Jews, which left for the forest every day at four in the morning. It was in these inhumane conditions that each day, when he returned from the forest, where he worked as a logger and was shouted at and insulted by the German soldiers, he entrusted notes, aphorisms, and thoughts to a series of small notebooks, which we now leaf through in the attempt to reconstitute, after the event, the genesis of his work. We do so on the basis of the accumulated fragments, in which philosophical reflections intermingle with references to the biblical and Talmudic tradition, excerpts from novelistic texts, which Levinas copied out rigorously, and the drafts of three novels, of which two remained unfinished: Eros and La dame de chez Wepler. For the condition of being hostage was paradoxical in that it allowed the prisoners, who suffered the most severe mistreatment during the day, to go to the library in the late afternoon. Reading, writing, and copying out excerpts represented for Levinas spaces of survival in the face of "the terrible reality that wove itself back together" (Levinas 2009, 72). Later, in an interview, Levinas will return to this experience, which he likens in the Carnets de captivité to a "monastic or moral life," evoking reading that he would never had done had he not been in captivity.

In making you a hostage, you are punished for someone else. For me, this term has no other meaning, except that it receives in this context a meaning that can be glorious. This misery of the hostage has a certain glory, to the extent that the person who is hostage knows that he runs the risk of being killed for someone else. In this condition of being hostage, however, which I call "the uncondition of the hostage," is there not a supreme dignity beyond the dramatic fate?

(de Saint-Cheron 2006, 31)

\section{Condition and Uncondition}

Is it possible to expose and thematise the figure of the hostage when one is oneself a hostage? Is it possible to pass from the lived experience of the condition of being hostage to the philosophical experience of the uncondition of being hostage without letting this question, which was posed in the traumatism of historical time, return within the order of that which Levinas seeks to exceed? What can be made of the transition from the Said of captivity to the Saying of the hostage? Can one translate the other without betraying him? It 
would be through an unsaying oneself that is never attained, always begun anew, that Levinas would come to interpret the meaning of the Said pertaining to the hostage of lived experience, by submitting it to the irreducibility of the Said in the uncondition of the hostage. This is the locus where philosophical thought would be developed that would open into what Levinas, in the Carnets de captivité, calls the “[c]orporeal meaning of time" (Levinas 2009, 186). Levinas operates this corporeal meaning of time on the basis of the incessant reading of Proust he carries out when he is prisoner of war. In Proust, human being does not derive merely from the dialectic of historical totality and eschatological rupture. It is always in a constitutive tension with the pure meaning of the other, thus excluding objective disclosure and extracting it from a political and historical order. As Levinas notes in the Carnets de captivité, "All the history of Albertine as a prisoner is the history of the relation to the other" (Levinas 2009, 72). In the same way, the amorous and erotic approach to the other in Proust is not due to the directness of the face and of the word. It comes to pass in the equivocal and meaningful silence that, in Levinas, will become in Totalité et infini the intentionality of the caress as the sensual moment that "transcends the sensual" and that by transcending it allows one to attain the duality proper to the incommensurable mystery of the other. This mystery is for Levinas, from the beginning of the Carnets de captivité, "the very basis of love" (Levinas 2009, 114). The motif of sexuality, which is very present in the Carnets, is from now on broached as constituting egoity. In 1942, between a reflection on Joseph de Maistre and Alfred de Vigny and an allusion to the festival of Simhat Torah (October 4, 1942), Levinas copies this brief passage of Albertine disparue:

I never stopped loving myself, for my daily relations with myself had not been ruptured as had those with Albertine. But what if those with my body, with myself, had also been? Certainly, it would be the same. Our love of life is nothing other than an old liaison that we cannot get rid of. Its force lies in its permanence. But the death that rends it will cure us of the desire for immortality.

(Levinas 2009, 77)

One could make a very precise summary of the themes that provide the foundation for Proustian subjectivity and we could place them, in a systematic manner, in relation to Levinassian idioms: love, eroticism, sexuality, sociality, signifyingness and signification, ethical structure of the subjectivity of the onefor-the-other, death as refractory to experience, the moment in which the heterogeneous imposes itself as Other such that it is Wholly Other, the impossibility of recuperating the wholly Other into the same, the feminine assimilated to the figure of the Other "before the Other is another person" (Levinas 2009, 76). These themes can be thought of as narrative-philosophical attestations of 
which one finds an archaeological and genetic trace in the Carnets and which, in Autrement qu'être, Levinas articulates around one single question: what becomes of subjectivity when it is exposed to the alterity of the other?

This duality of a subject simultaneously exposed to the alterity of the other and of a subject reposing substantially in itself - that which Levinas calls the other-in-the same exposed to an "in-spite-of-oneself" - characterises what we call here the "literary instant." The reading of Proust represents one of the foundational moments of this questioning. Proustian subjects are all determined by a subjective identity that never coincides with itself. Thus, one could inscribe the speculative movement of Levinas's thought into the narrative moments of Proust's writing and deduce from there, on the basis of the three cases of Love, Alterity, and Subjectivity, in the phenomenological sense of the term, what it means to "show what a person is when facing the other" (Levinas 2009, 145). Proust is therefore one of the pivots around which Levinas's rupture with substantialism turns for the benefit of the real emergence of the intersubjectivity of love. This rupture is not possible unless one effects a movement of substitution, a movement by which one passes from the act as the first manifestation of substance to "the voluptuosity that is neither act nor thought" (Levinas 2009, 144). Levinas's effort consists in articulating the question of voluptuosity with that of sociality and of radical alterity. He writes:

When I say that Proust is a poet of the social and that all his work consists of showing what a person is when facing another, I do not want to simply evoke the old theme of the fatal solitude of every being (cf. Estaunié's Solitudes) - the situation is different: to a being, all of the other is hidden - but a separation does not result from this. It is precisely the fact of hiding oneself that is the ferment of social life. It is my solitude that interests the other and all his comportment is movement around my solitude. This is Marcel and Albertine. The so voluminous work of Proust culminates in these two themes of Albertine as a prisoner and as possessed, which is not distinct from Albertine who has disappeared and died. The torment that constitutes his relation to her lies in the fact that there are many things about her - simple things, attitudes, gestures, poses - that he will never know. And what he knows about her is dominated by what he will never know, because all the objective evidence is less powerful than the doubts that will remain within him forever - and that comprise his relation with Albertine.

(Levinas 2009, 145)

\section{Genesis and Genetics of a New Thought}

If the appearance of the first volume of Emmanuel Levinas's unpublished writings allows one to trace and reconstitute in a quasi-genetic manner the premises of a thought that investigates the status of writing, it is to a large part thanks to the discovery, in the Carnets de captivité, of the explicit abundance of 
literary references, and above all the discovery of what few interpreters and specialists of Levinas's work knew about: Levinas's ambition, his clearly expressed vocation, to conceive his work as a constellation that articulates philosophy with literature and criticism.

In the first notebook, begun on September 8, 1937, Levinas notes:

My work to be done:

$\begin{array}{ll}\text { Philosophical : } & \text { 1) Being and nothingness } \\ & \text { 2) Time } \\ & \text { 3) Rosenzweig } \\ & \text { 4) Rosenberg } \\ \text { Literary: } & \text { 1) Sad opulence } \\ & \text { 2) Irreality and love } \\ \text { Criticism: } & \text { Proust (Levinas 2009, 74) }\end{array}$

I would like, then, to comment on Proust, emphasising the idea that Levinas indeed expressed the wish to carry out a work of criticism - just like his friend Maurice Blanchot, who, in the 1920s, when they were students in Strasbourg, had introduced him not only to the work of Proust but also to that of Léon Bloy, whose great importance for Levinas one measures with admiring astonishment on reading the Carnets and the laudable pages that he devotes to the author of the Lettres à sa fiancée (1889-1890). These are two writers from whom Levinas, throughout the five years of his captivity, carefully excerpts fragments of narratives that are like the mimetic possibility of responding in his own language, in wresting it from the impersonal and inhuman il y $a$ of the condition of being hostage, in such a way as to let surge forth the materiality of language having become thing, the experience thing, which, in the seventh and last notebook, Levinas calls the "corporeal meaning of time" (Levinas 2009, 186).

Many writers file past in the course of the notebooks, too many to be cited in the general economy of my remarks, but Léon Bloy, whom I shall not dwell on, and Marcel Proust each require a gesture of writing that is a powerful movement of transcendence within immanence. There is a way in which Levinas considers this movement of transcendence, this liberating of the Heideggerian immanence of being, as being carried out in the literature of Bloy and Proust. Levinas does not hesitate to express a sentence with respect to Bloy that we should meditate upon at length, for it brings about the defection from the Husserlian intentionality that Levinas decries: "He knows things that are not in phenomenology" (Levinas 2009, 162). This is an admirable perception of narrative time in search of a true beyond-being, which draws its inspiration from a meditation on the negativity of death, dismissing momentarily the spiritualism 
of German Idealism, which sees in it, in the nothingness of death, the condition of the life of the Spirit. It is thus at an extreme point of excess and of exceeding that Levinas, in captivity, reads and excerpts Bloy and Proust, and, even if he denies this, one cannot exclude the possibility that he lived this literary instant as an experience of "consummation," such as the one he speaks of in De l'existence à l'existant. ${ }^{3}$ This would be the possibility of descrying absolute exteriority from the very interior of his reflection, the exteriority that he will attain in the final chapter of Autrement qu'être. So, too, in Proust, the emotion and the meaning borne by writing are constantly released by a movement of reflexivity with respect to his own emotion, "and even more often," Levinas says in speaking of Proust, "by reflection on the emotion of the other. Still better: this reflection is this very emotion" (Levinas 2009, 71).

Once more, the trope of excess contained in the idea of a reflection as the paradigm of an emotion induces in Levinas a reading of Proust, an aspect of which we already know in the essay he devotes to him in Noms propres (1976), “L'Autre dans Proust.” Indeed, Levinas always weaves his discourse on Proust and on what develops from him by connecting him to an ambivalent interpretation dividing itself into two contrary movements ${ }^{4}$ at the heart of transcendence, thus calling forth an irreconcilable diachrony in the temporality of the narrative. I shall borrow from Jean Wahl the designations he forged on the basis of the word "transcendence" in attempting to describe a double transcendence he detected in Kierkegaard's relation of subjectivity to the absolute. The first movement, "transcendence," would correspond, as its name indicates, to the return, to falling back to what lies before being, in the il y a that is obsessional and from which there is no way out, just as being rooted in the primordial earth or being rooted in the flesh, which would always presuppose the unpredictability of the interpellation of a word come to rupture and interrupt this rootedness. These are the moments in which, according to Levinas, Proust engages in the concrete, even exotic descriptions where the ethical structure of the loving face-to-face disappears or is diluted. This is the moment in which, in Proust's work, "magic begins, like a fantastic Sabbath, once ethics has finished" (Levinas 1976, 119). In the Carnets de captivité, these are the moments in which Levinas underlines the paradoxical and unattainable character, the enigma of the irrepressible attraction Albertine effects in all her nihilating power, which would be the annulling of

3 See Levinas, De l'existence à l'existant (1986, 93 and following).

4 The two expressions proper to these two contrary movements, "transdescendence" and "trans-ascendence," derive from Jean Wahl, Immanence et transcendance, "La transcendance intériorisée,” Traité de Métaphysique. Paris: Payot, 1957. 
the face. This annihilation would open onto a nothingness that would itself lead to nothing but the incommensurability of a subordination to an other that no longer recognises the traversing of alterity or, to speak like Hegel, a subordination that no longer recognises a thought of death that has to face the trial of nothingness by "looking it in the face" (Hegel 1988, 26) - a Hegelian reflection from which Levinas has broken. However far she abandons or extends herself, whatever the objective and loved alterity to which she refers, Albertine always remains identical with herself. She is, one could say, identity par excellence. Levinas comments:

What is Albertine (and her lies), if not the very evanescence of the other, her reality made from her nothingness, her presence made from her absence, the struggle with the ungraspable? And beside this - the calm of Albertine sleeping, of the vegetal Albertine. The "character," the "solid" = thing.

(Levinas 2009, 72)

Three fragments further on, Levinas continues his reflection, alternating between commentaries and extracts copied from Albertine disparue:

It is no longer a question of deciding between a certain pleasure - which has become almost nothing through habit or perhaps because of the mediocrity of its object - and other pleasures, which are on the contrary tantalizing, ravishing, but between those pleasures and something that is much stronger than them, the pity felt for suffering. Proust, Albertine disparue, I, p. 22.

(Levinas 2009, 73)

The second movement, that of "trans-ascendence," designates the metaphysical movement towards the Other, the movement of being affected by the other which happens through the body, through its temporal meaning and by the impossibility of quenching the metaphysical desire for the other - from whence the idea that sensibility is defined by vulnerability. This distinction between transdescendence and trans-ascendence is not truly thematised by Levinas. Yet it permeates Levinas's relation to literature; the relation is not identifiable as a philosophical proposition (énoncé) but as its perlocution (énonciation). It is the narrative Saying that acts deep below the philosophical Said. It is not a matter of a discourse of truth but of a word on the absolute ambiguity contingent upon the opposition between alterity and knowledge. Certainly, it is in death that the Other is most fertile, gnaws at us the most, that his alterity is the most unattainable, the least reducible to the mastery of knowledge. Levinas writes:

The illness itself is this thought of death (and aging and boredom) 2) Proust conceives this thought through illness or aging, which are a positive (and appropriate) access to a concept and without which we could only have a negative concept.

(Levinas 2009, 72ff.) 
Albertine's nothingness is therefore not a nothing. It is that which, as Levinas underlines in his essay on Proust, "discovers her total alterity." Death is not only her own death, "it is the death of the other, contrary to the contemporary philosophy attached to the solitary death of the self”' (Levinas 1976, 122)

This essential step taken by Levinas, this step not beyond (Blanchot), would have been in part, not exclusively, due to literature and in particular to the work of Proust. This is remarkable in never dividing between transdescendence and trans-ascendence. In it the two movements, in a single piece, join in their shared refusal to yield to Heideggerian being. It is the fact of leaving the ambivalence to a total ethical tension that makes the work of Proust at the same time "more and less than being" (Levinas 1976, 55). To me, this is the essential and decisive role of Levinas's reading of Proust in captivity. It is the locus where a paradoxical, although completely Husserlian, reflection on the question of experience is constituted, which Levinas will later take up in this extraordinary sentence that I place immediately in relation to the question of the temporal meaning of time: “The great 'experiences' of our lives were never, properly speaking, lived” (Levinas 2010, 294).

\section{The Corporeal Meaning of Time}

One finds here the Husserlian analysis of inner time-consciousness again, but this is articulated in the modality of the corporeal meaning of time, in lived experience, in the incessant passage of the Said to the Saying and to the Unsaying, inner time-consciousness no longer coming to support totally the concept of a transcendental egoic consciousness and intentionality. The important experiences of one's life, which are never properly speaking lived, are situated at the point of intersection where the inner consciousness of time is caught in the ellipse of temporal meaning, pushing it towards the extreme limits, to the point of rupture with the intentional objects that no longer belong to consciousness as constitutive moments but are rather recognised in their full transcendence and ideality. Experience is thus of a perceptive nature, pre-predicative, completely transformed by the flowing temporality of lived experience and of intentional acts. The phenomenon of the retention of lived experience flowing and flowing away in the protention of what is about to be and at the same time has not yet come always remains suspended in the coming or occurrence of an event, in an "awakening" that has nothing to do with a phenomenon of recollection or with a synthesis of recognition. 
The decisive gesture carried out by Levinas consists in no longer thinking in two temporal registers - the one active, i.e., retention, the other passive, i.e., protention - but in apprehending the subject as "passivity in its very origin" (Levinas 1974), which will not become active again save in a secondary and lateral manner. The important experiences of our life that we have not experienced - and all Levinas's work is an admirable exemplification of this, or a true narrative phenomenality - are such because the passivity of the subject is no longer thought as the Same that has already been constituted, that will subsequently encounter the other. The passivity of the subject is thought originally as the Other-in-the-Same, the Other, which, according to Hegel, has opened the Same to the Other. In the case of Proust, according to Levinas's reading in captivity, the interest consists not in a perception that would reduce the sources of consciousness in impressions to a psychological analysis of characters and of action. The interest lies, as Levinas determines, "in the theme: the social" (Levinas 2009, 72).

The manner in which Levinas introduces the motif of sociality is completely remarkable, for this does not enter into contradiction with the idea of a subjecthostage who undoes the relation of retention to protention, who undoes the precise moment in which the intentionalities, as intention and event, coincide. The other motif must be re-introduced here, that of passivity, of a passivity more passive than all passivity, according to the expression that Levinas never ceases to rearticulate. ${ }^{5}$

The subject-hostage exposes itself to the other without an intended expectation, without a destination already present in inner time-consciousness. His passivity is without assumption, like "a skin exposes itself to that which hurts it" (Levinas 1974, 63). Faced with assignation by the other, passivity does not retrench itself in a time behind time. Passivity is to be understood as a return to time itself, thus a social time, which cannot be counted before its limits. This does not mean, however, that it issues forth from nowhere or out of no time. Passivity is not negativity, either. It is just as infinite as responsibility or proximity and is thus just as difficult to grasp. That is why passivity is responsible for a time-lag that it cannot fill. Nothing synchronic is possible, no symmetry, because it is at the same time the retaining and the protaining of what will never coincide. The passivity of the subject-hostage is passive despite itself. It lives off its "total patience" (Levinas 1974, 86) and in doing so it reaches the other without ever showing itself. Passivity has thus renounced being contemporary to what it wishes to reach and touch. From this comes

5 See Levinas, Autrement qu'être (1974, 18 and passim). 
the idea, very present in Levinas in the Carnets de captivite, that erotic desire, which he calls "human sexuality," is of the order of an irritation (Levinas 2009, 182). Eros is the basis of this irritation just as it is the basis of sociality for Levinas. It is the issue of a central question, of a dimension of Levinas's thought that the Carnets de captivité reveal to us in a decisive manner. On one hand, Levinas defines his philosophy, since the period of his captivity, as a philosophy of the face to face, of panim el panim, which in Hebrew is said not in the singular but in the plural - faces to faces. On the other hand, this face to face, which is proper to the erotic relation, exceeds the general motif of existence. In Levinas, the motif of existence means affliction, subjugation, languor of being, and not passivity. This presence of myself for a subjugated self constitutes a hope for Levinas. If eros is at the origin of the social, it is because the social is already in being. It is the very basis of the duality of I-for-myself and of the mystery of the other that opens to an intimacy not synonymous with fusion. It is on the basis of the motif of carnal concupiscence that Levinas describes the process of this duality. This duality, not understood, not heard as the phenomenon of fusion, thus opens onto an intimacy that is "the sum of the individuals" (Levinas 2009, 66), in other words, the social. The double relation here temporalises the relation of the I-for-myself to the other by freeing it from itself. The duality is already in itself a figure of time, of a dramatic time, because it is always confronted by the mystery of the other, which it will never reach or join. Yet precisely this temporal detachment between the duality of I-for-myself proper to sexuality as constitutive of egoity and the mystery of the other is the condition that allows one to go beyond the antagonism between egoism and altruism. Here there is "[r]upture with the ancient conception of love" (Levinas 2009, 114), thus the possibility of a true exteriority. This opening belongs to two orders, simultaneously the sexual and the social. Erotic desire temporalises the relation to the other that prevents being from foundering and taking its pleasure in its annihilation. Levinas names this hope for a freed present the "caress": "It is not loquacious, it does not say that things will be better - but it redeems in the present itself. Now, with the caress - we have (the) tender and the carnal. Corporeal meaning of time" (Levinas 2009, 186).

Pure suffering, therefore, is not a category. It is not the consequence of a pure sensation. It is in suffering and in submitting, in this absolute passivity, more passive than passivity, that the shivering of election lies, in the sense in which eros bears you towards the other, in the sense "of the love of a person who softly touches (caresses) you” (Levinas 2009, 180). This being carried towards - which is the very opposite of an arbitrary vision of the world, the very opposite of the numbness of the being to being, the very 
opposite of one being that is two - opens to a horizon of sociality and filiality, because the passage from one being that is two to "two beings in the instant” (Levinas 2009, 178) takes place in a relation of asymmetry. Levinas makes it more precise: "One can let go here." And he adds: "But one does not let go” (Levinas 2009, 178).

Here it is, the drama of the temporalisation of the subject's time. The latter seeks to interrupt this synthesis of voluntary, active, and triumphant cognition by opposing a passive synthesis to it that would be the synthesis of the very temporality of passivity. The only possibility - the only hope! - of interrupting the muffled and tenacious perseveration of being in its being and of overcoming the ontological obstinacy of the being-in-itself and for-itself. What then becomes of the relation of transcendence? Would it not be the hope for the for-the -other in the being that posits itself?

If lived experience can only be thought proceeding from the relation of the for-the-other, on the basis of the question that is posed as much by the mortality of the Other as by the metaphysical and erotic desire for the Other, then the relation of transcendence is always referred to a social continuity, which Levinas presents as a relation of delay, of the irreconcilable gap between who comes, who goes, and who is already here. To have a rendezvous with the other is always to be late for him, whatever happens. In taking one's point of departure in Blanchot's formula - "together and still not" one could say that for Levinas it would be a question of being together and yet never.

The pages of Proust on which Levinas comments show well that the passive and inordinate relation of love tied to Albertine is always already concealed in the society to which the subject belongs. This is why ultimate and radical passivity, Levinas's so extravagant gesture, is necessary in order to think of "madness" (Levinas 1974) - that which assaults the human and conditions his relation to time imperatively, that which he cannot approach without desisting from it at the same time.

For Levinas, then, calling on the interiority proper to Proustian narration is not a way of escaping lived experience; rather, it is a means of penetrating deeper into the exigencies of the ethical vocation of the narrative beyond the facticity of the history always seeking to utter itself or not to utter itself in thematising itself. Ultimate meaning escapes it, however, for the relation of the subject-hostage to the other is dissymmetrical, just as is the irreversibility of time. The indelible traces of this in the structure of the meaning narrated do not belong to any formal logic but derive from an infinite moment of un-saying and of re-saying that is one of the characteristics of the disinterestedness of love. 


\section{Bibliography}

Barthes, Roland. Euvres Complètes, vol. 3. Paris: Seuil, 2002.

Hegel, Phänomenologie des Geistes. Eds. Hans-Friedrich Wessels and Heinrich Clairmont. Hamburg: Meiner, 1988.

Levinas, Emmanuel. Autrement qu'être ou au-delà de l'essence. The Hague: Nijhoff, 1974. Levinas, Emmanuel. Noms propres. Paris: Vrin, 1976.

Levinas, Emmanuel. De l'existence à l'existant. Paris: Vrin, 1986.

Levinas, Emmanuel. Les imprévus de l'histoire. Montpellier: Fata Morgana, 1994.

Levinas, Emmanuel. Oeuvres, 1: Carnets de captivité et autre inédits. Eds. Rodolphe Calin and Catherine Chalier. Paris: Grasset/IMEC, 2009.

Levinas, Emmanuel. En découvrant l'existence avec Husserl et Heidegger. Paris: Vrin, 2010. de Saint-Cheron, Michel. Entretiens avec Emmanuel Levinas (1992-1994). Paris: Le livre de poche, 2006. 
